\title{
STUDIES ON STAPHYLOCOCCI
}

\author{
II. Effect of Coagulase on the Virulence of Coagulase Negative Strains ${ }^{1}$ \\ RICHARD D. EKSTEDT ${ }^{2}$ AND WILLIAM W. YOTIS ${ }^{3}$ \\ Department of Microbiology, Northwestern University Medical School, \\ Chicago, Illinois
}

Received for publication February 23, 1960

In a previous report (Yotis and Ekstedt, 1959) it was shown that partially purified coagulase markedly increased the oxygen consumption of coagulase negative strains of Staphylococcus aureus, using normal human serum as substrate. Human serum possesses an antistaphylococcal factor which is directed primarily against coagulase negative organisms (Ekstedt and Nungester, 1955; Ekstedt, 1956a, $b$ ). Coagulase neutralized the serum factor, allowing coagulase negative strains to grow in human serum as well as do coagulase positive strains.

A logical extention of this work was to determine the effect of purified coagulase in vivo. Many investigators (Smith, 1947; Smith and Dubos, 1956) have observed a close correlation between coagulase activity and virulence in this group of microorganisms. To our knowledge, however, there has been no direct demonstration of the function of coagulase in an experimental staphylococcal infection. It was felt that a study of the effect of purified coagulase upon the virulence of staphylococci would be worthwhile.

The results show that the mouse virulence of coagulase negative staphylococci can be enhanced by injecting the organisms suspended in solutions of partially purified coagulase. Further observations of the mechanism and specificity of this phenomenon will be described.

\section{MATERIALS AND METHODS}

Cultures. The source, maintenance, and cultivation of cultures used in this investigation

1 This work was supported in part by contract DA-49-007-MD-982 with the Department of the Army, Office of the Surgeon General, under the sponsorship of the Commission on Streptococcal and Staphylococcal Diseases, Armed Forces Epidemiological Board.

2 Fellow of the Helen Hay Whitney Foundation.

${ }^{3}$ Postdoctoral fellow, Department of Microbiology, Northwestern University. has been described (Yotis and Ekstedt, 1959). Inocula for virulence studies were grown in 100 $\mathrm{ml}$ brain heart infusion broth (Difco) for $18 \mathrm{hr}$ at $37 \mathrm{C}$. The cells were harvested by centrifugation, washed 3 times with distilled water, resuspended in $10 \mathrm{ml}$ sterile distilled water, and a smooth suspension made by manual shaking for 3 to $5 \mathrm{~min}$ in a 125-ml Erlenmeyer flask, containing 20 to 30 glass beads each having a diameter of $5 \mathrm{~mm}$. Following this treatment it was found by direct microscopic observation that the majority of the cells occurred singly or in pairs. Clumps observed never contained more than 6 cocci. The suspension was adjusted to an optical density of 0.1 at a wavelength of $420 \mathrm{~m} \mu$ on a Coleman spectrophotometer, and contained an average of $5.3 \times 10^{8}$ viable cells per $\mathrm{ml}$.

Virulence studies. Groups of 6 to 12 normal male Swiss mice weighing 18 to $21 \mathrm{~g}$ were injected intracerebrally with $0.03 \mathrm{ml}$ of the standard cell suspension, using a $0.25-\mathrm{ml}$ syringe and a 27 gauge needle.

In the virulence enhancement studies, 5.0 $\mathrm{ml}$ of the standardized cell suspension were mixed with $0.2 \mathrm{ml}$ of the purified coagulase preparation, containing $5 \mathrm{mg}$ coagulase, incubated $1 \mathrm{hr}$ at $37 \mathrm{C}$, and injected in $0.03-\mathrm{ml}$ amounts as described above. The coagulase solution was heated at $60 \mathrm{C}$ for $30 \mathrm{~min}$ before it was added to the cell suspensions to inactivate any $\alpha$-toxin present. This treatment had no effect on the coagulase activity of the preparation.

In some experiments the cells, after exposure to the coagulase, were centrifuged out, resuspended in the same volume of sterile distilled water, and injected as described above. Control groups of animals were injected in all experiments with organisms alone or coagulase alone at the same concentrations.

Coagulase purification and titration. Partially purified coagulase was prepared using the 
methods described by Tager (1948), and titrated as previously described (Yotis and Ekstedt, 1959). The preparation used in these studies clotted 1:5 diluted fresh rabbit plasma at a concentration of $0.005 \mu \mathrm{g}$ per $\mathrm{ml}$.

TABLE 1

Mouse virulence of staphylococcal strains

\begin{tabular}{l|l|l|l|l}
\hline $\begin{array}{c}\text { Expt } \\
\text { No. }\end{array}$ & $\begin{array}{c}\text { No. of } \\
\text { Animals }\end{array}$ & Inoculum* & \multicolumn{2}{|c}{ Per Cent Mortality after } \\
\hline
\end{tabular}

Coagulase Positive Strains

\begin{tabular}{|c|c|c|c|c|c|}
\hline 1 & 5 & $4.7 \times 10^{7}$ & 80 & 80 & 80 \\
\hline 2 & 6 & $5.5 \times 10^{7}$ & 83 & 83 & 83 \\
\hline 3 & 6 & $3.5 \times 10^{6}$ & 83 & 100 & 100 \\
\hline 4 & 6 & $4.3 \times 10^{7}$ & 83 & 100 & 100 \\
\hline 5 & 6 & $3.1 \times 10^{7}$ & 83 & 100 & 100 \\
\hline 6 & 6 & $9.3 \times 10^{6}$ & 50 & 50 & 50 \\
\hline 7 & 6 & $4.2 \times 10^{6}$ & 83 & 83 & 83 \\
\hline 8 & 6 & $7.9 \times 10^{6}$ & 83 & 100 & 100 \\
\hline 9 & 6 & $7.1 \times 10^{6}$ & 66 & 66 & 66 \\
\hline 10 & 6 & $1.5 \times 10^{6}$ & 66 & 66 & 83 \\
\hline 11 & 6 & $3.5 \times 10^{6}$ & 50 & 66 & 83 \\
\hline 12 & 6 & $3.4 \times 10^{6}$ & 17 & 33 & 33 \\
\hline 13 & 6 & $3.3 \times 10^{6}$ & 66 & 83 & 83 \\
\hline 14 & 6 & $1.8 \times 10^{6}$ & 50 & 66 & 66 \\
\hline 15 & 6 & $3.7 \times 10^{6}$ & 66 & 66 & 66 \\
\hline 16 & 6 & $1.6 \times 10^{6}$ & 66 & 66 & 66 \\
\hline \multicolumn{2}{|c|}{ Mean } & $1.4 \times 10^{7}$ & 67.1 & 75.4 & 77.5 \\
\hline
\end{tabular}

\begin{tabular}{|c|c|c|c|c|c|}
\hline \multicolumn{6}{|c|}{ Coagulase Negative Strains } \\
\hline 1 & 6 & $2.2 \times 10^{7}$ & 17 & 17 & 17 \\
\hline 2 & 5 & $7.8 \times 10^{6}$ & 0 & 0 & 0 \\
\hline 3 & 6 & $5.1 \times 10^{7}$ & 0 & 0 & 0 \\
\hline 4 & 6 & $7.0 \times 10^{7}$ & 0 & 0 & 0 \\
\hline 5 & 6 & $4.1 \times 10^{6}$ & 17 & 33 & 33 \\
\hline 6 & 6 & $2.2 \times 10^{6}$ & 0 & 0 & 0 \\
\hline 7 & 6 & $3.7 \times 10^{6}$ & 0 & 0 & 0 \\
\hline 8 & 6 & $1.5 \times 10^{6}$ & 0 & 0 & 0 \\
\hline 9 & 6 & $8.7 \times 10^{6}$ & 0 & 16 & 16 \\
\hline \multicolumn{2}{|c|}{ Mean } & $1.9 \times 10^{7}$ & 3.5 & 7.1 & 7.1 \\
\hline
\end{tabular}

\begin{tabular}{l|l|l|l|l|l}
\hline \multicolumn{7}{|c}{ Saline Control } \\
\hline 1 & 6 & - & 0 & 0 & 0 \\
2 & 6 & - & 0 & 0 & 0 \\
\hline
\end{tabular}

* Inoculum is number of organisms injected intracerebrally in $0.03 \mathrm{ml}$ volume.

\section{RESULTS}

Survey of strains. A group of 25 strains of $S$. aureus was selected; sixteen were coagulase positive and 9 coagulase negative. All were hemolytic on rabbit blood agar plates. These organisms were assayed for mouse virulence by intracerebral challenge as described. As can be seen in table 1, at the dose level used, all of the coagulase positive strains were rapidly fatal, whereas the coagulase negative strains had little effect under the same conditions.

Although no attempt was made to quantitate the distribution of the microorganisms in the tissues of the animals, cultures of the brain, kidneys, spleen, lungs, and blood at autopsy indicated that the infection remained localized in the brain with death resulting from the formation of an extensive purulent abscess.

Enhancement of virulence by coagulase. Three strains of coagulase negative staphylococci were grown and prepared for challenge as described above. Five separate experiments were performed and the results are presented in table 2 . As is evident, in every case in which the organisms were injected along with partially purified coagulase, there was a marked increase in the mortality observed. The organisms alone or the coagulase alone at the same concentrations were completely innocuous.

In a subsequent experiment, the cells after exposure to the coagulase were centrifuged out and resuspended in sterile distilled water for injection. Analysis of the coagulase negative cell suspension after treatment showed that they had adsorbed a considerable amount of coagulase activity from the solution. After exposure to the coagulase solution the cells had a coagulase titer of $1: 81,920$, whereas the coagulase solution had decreased from an original titer of 1:100,000 to $1: 1280$ after adsorption. The results of experiments of this kind are shown in table 3 . It is evident that coagulase negative staphylococci when exposed to coagulase followed by the removal of excess unadsorbed coagulase still show an increased virulence.

To determine the specificity of the coagulase solutions in enhancing the virulence of coagulase negative staphylococci, 6 per cent solutions of egg albumin, human serum, and dextran were used to suspend the organisms. The results of these experiments are also shown in table 3 . It is clear that with the conditions described, nonspecific 
TABLE 2

Enhancement of mouse virulence of coagulase negative staphylococcal strains by coagulase

\begin{tabular}{|c|c|c|c|c|c|c|}
\hline \multirow{2}{*}{ Expt No. } & \multirow{2}{*}{ Strain No. } & \multirow{2}{*}{ No. of Animals } & \multirow{2}{*}{ Inoculum* } & \multicolumn{3}{|c|}{ Per Cent Mortality after } \\
\hline & & & & 3 days & 7 days & 14 days \\
\hline $\begin{array}{l}1 \\
2 \\
3 \\
4 \\
5\end{array}$ & $\begin{array}{l}141 \\
141 \\
111 \\
111 \\
117\end{array}$ & $\begin{array}{r}20 \\
14 \\
11 \\
19 \\
8\end{array}$ & $\begin{array}{l}2.3 \times 10^{6} \\
1.2 \times 10^{6} \\
3.2 \times 10^{6} \\
2.7 \times 10^{6} \\
2.3 \times 10^{6}\end{array}$ & \begin{tabular}{c|}
10 \\
14.3 \\
0 \\
33 \\
50
\end{tabular} & \begin{tabular}{l|}
28 \\
21.4 \\
27.4 \\
44.4 \\
50
\end{tabular} & $\begin{array}{l}43 \\
50 \\
37.3 \\
55.5 \\
50\end{array}$ \\
\hline \multicolumn{3}{|l|}{ Mean... } & $2.34 \times 10^{6}$ & 21.4 & 34.0 & 47.2 \\
\hline $\begin{array}{l}\text { Cell control } \\
\text { Coagulase control }\end{array}$ & & $\begin{array}{l}5 \text { in each experiment } \\
5 \text { in each experiment }\end{array}$ & Same as above & $\begin{array}{l}0 \\
0\end{array}$ & $\begin{array}{l}0 \\
0\end{array}$ & $\begin{array}{l}0 \\
0\end{array}$ \\
\hline
\end{tabular}

* Inoculum is number of organisms injected intracerebrally in $0.03 \mathrm{ml}$ coagulase solution.

TABLE 3

Enhancement of mouse virulence of coagulase negative staphylococcal strains by various substances

\begin{tabular}{|c|c|c|c|c|c|}
\hline \multirow{2}{*}{ Challenge Material } & \multirow{2}{*}{$\begin{array}{l}\text { No. } \\
\text { of } \\
\text { Ani- } \\
\text { mals }\end{array}$} & \multirow{2}{*}{ Inoculum* } & \multicolumn{3}{|c|}{$\begin{array}{c}\text { Per Cent } \\
\text { Mortality after }\end{array}$} \\
\hline & & & days & $\begin{array}{c}7 \\
\text { days }\end{array}$ & $\begin{array}{l}14 \\
\text { days }\end{array}$ \\
\hline Cells + coagulase & 25 & $2.8 \times 10^{6}$ & 12 & 32 & 52 \\
\hline $\begin{array}{c}\text { Cells }+ \text { coagulase } \\
\text { (centrifuged) } \dagger\end{array}$ & 21 & $2.6 \times 10^{6}$ & 14 & 33 & 48 \\
\hline $\begin{array}{l}\text { Cells + egg al- } \\
\text { bumin }\end{array}$ & 6 & $2.9 \times 10^{6}$ & 0 & 0 & 0 \\
\hline $\begin{array}{l}\text { Cells }+ \text { human } \\
\text { serum }\end{array}$ & 6 & $2.7 \times 10^{6}$ & 0 & 0 & 0 \\
\hline Cells + dextran & 6 & $2.4 \times 10^{6}$ & 0 & 0 & 0 \\
\hline Cell control & 6 & $2.6 \times 10^{6}$ & 0 & 0 & 0 \\
\hline Coagulase control & 6 & 一 & 0 & 0 & 0 \\
\hline
\end{tabular}

* Inoculum is number of organisms injected intracerebrally in $0.03 \mathrm{ml}$ volume.

$\dagger$ Cells after exposure to coagulase were centrifuged and resuspended in the same volume of sterile distilled water.

protein and polysaccharide produce no enhancement of the virulence of coagulase negative staphylococci.

Attempts were made to show an enhancement of virulence by injecting the coagulase intravenously followed immediately by intracerebral challenge. The results of these experiments were negative, both control and treated animals survived the standard challenge. Attempts were also made to enhance the virulence of group $A$
TABLE 4

Enhancement of mouse virulence of staphylococcal strains by varying amounts of coagulase

\begin{tabular}{|c|c|c|c|c|c|}
\hline \multirow{2}{*}{ Coagulase Concn* } & \multirow{2}{*}{$\begin{array}{l}\text { No. of } \\
\text { Animals }\end{array}$} & \multirow{2}{*}{ Strain } & \multicolumn{3}{|c|}{$\begin{array}{c}\text { Per Cent } \\
\text { Mortality after }\end{array}$} \\
\hline & & & $\stackrel{3}{\text { days }}$ & $\begin{array}{c}7 \\
\text { days }\end{array}$ & $\begin{array}{c}14 \\
\text { days }\end{array}$ \\
\hline$m g$ & & & & & \\
\hline $10^{-1}$ & 6 & 111 & 17 & 33 & 50 \\
\hline $10^{-2}$ & 6 & 111 & 33 & 50 & 50 \\
\hline $10^{-3}$ & 6 & 111 & 0 & 0 & 0 \\
\hline $10^{-4}$ & 6 & 111 & 0 & 0 & 0 \\
\hline $10^{-5}$ & 6 & 111 & 0 & 0 & 0 \\
\hline Cell control & 6 & 111 & 0 & 0 & 0 \\
\hline Coagulase control & 6 & - & 0 & 0 & 0 \\
\hline $10^{-1}$ & 6 & 141 & 33 & 33 & 50 \\
\hline $10^{-2}$ & 6 & 141 & 50 & 50 & 50 \\
\hline $10^{-3}$ & 6 & 141 & 17 & 33 & 33 \\
\hline $10^{-4}$ & 6 & 141 & 17 & 17 & 17 \\
\hline $10^{-5}$ & 6 & 141 & 0 & 0 & 0 \\
\hline Cell control & 6 & 141 & 0 & 0 & 0 \\
\hline Coagulase control & 6 & - & 0 & 0 & 0 \\
\hline
\end{tabular}

* Each animal received $0.03 \mathrm{ml}$ of the standard cell suspension containing $2.6 \times 10^{6}$ organisms and the stated $\mathrm{mg}$ of partially purified coagulase.

streptococci by injecting them along with partially purified coagulase without success.

Quantitative aspects of virulence enhancement. The amount of partially purified coagulase necessary to show the virulence enhancing effect was determined. A solution of coagulase in saline containing $33.3 \mathrm{mg}$ per $\mathrm{ml}$ was diluted serially 
by 10 -fold dilutions. To $1.0 \mathrm{ml}$ of each dilution $9 \mathrm{ml}$ of a standardized cell suspension were added, giving coagulase concentrations from $10^{-1}$ to $10^{-5} \mathrm{mg}$ per $0.03 \mathrm{ml}$. Groups of 6 mice each were injected intracerebrally with each of the suspensions. Table 4 shows the results obtained with two different strains of coagulase negative staphylococci. It is clear that if clotting is taken as the criterion of activity, the coagulase preparations used can be diluted much farther than when virulence enhancement is used as the criterion of activity.

\section{DISCUSSION}

Although coagulase has been tacitly assumed to play an important role in the virulence of staphylococci, and is considered by most to be the best single criterion to use in estimating the potential pathogenicity of a strain, no direct demonstration of its role in the pathogenesis of infection with these organisms has been made. The results presented here show that when avirulent, coagulase negative staphylococci are suspended in solutions of partially purified coagulase and injected intracerebrally into mice, a marked increase in the virulence of the organisms results.

These results might have been interpreted as being due to a nonspecific lowering of host resistance by the coagulase in a manner similar to mucin or other substances of this type. Experiments with the streptococci as well as those in which coagulase was given by a different route made this interpretation untenable.

It is quite possible that coagulase functions as a surface antigen in a manner similar to the specific polysaccharide of the pneumococcus or the M-protein component of group A streptococci. Recent work of Cohn and Morse (1959) shows that at least with rabbit leukocytes, coagulase positive staphylococci resist phagocytosis in an in vitro system, whereas coagulase negative staphylococci are more readily ingested and destroyed. Boake (1956) has also shown a significant degree of protection in rabbits immunized with partially purified coagulase.

It would seem quite possible that by adsorption of coagulase to coagulase negative staphylococci these organisms might be protected either from some normal bactericidal serum factor or from phagocytosis and destruction by the leukocytes.
It is probable that the fate of the experimentally infected animal is decided shortly after the challenge infection is given. If the microorganisms can protect themselves against the natural defense mechanisms of the host for a time sufficient to begin multiplying, the host is overwhelmed in spite of normally functioning defense mechanisms.

The necessity of using relatively large amounts of purified coagulase to demonstrate the enhancement of virulence may be due to the rapid destruction of this material in the tissues of the animal. Walker, Schaffer, and Derow (1947) have shown that coagulase is relatively susceptible to inactivation by proteolytic enzymes.

It should be made clear at this point that although the coagulase preparations used in this study were highly purified it is always possible that there are other substances of bacterial origin contaminating the preparations, and responsible for the activities described. Recently Wlodarczak and Jeljaszewicz (1959) in a brief communication confirmed our earlier work with crude coagulase preparations, but indicated that "highly purified" coagulase preparations were inactive in neutralizing the antistaphylococcal activity of human serum. These results are difficult to interpret in view of the lack of adequate data. Nevertheless, until more highly purified coagulase is available, question of its postulated activities will arise.

It should also be pointed out that these experiments were done with hemolytic strains of $S$. aureus. It is quite possible that had nonhemolytic, coagulase negative strains of Staphylococcus albus been used, no enhancement of virulence would have been possible. In other words, we do not wish to give the impression that coagulase is the only factor important in determining the virulence of staphylococci. It is clear from the work of Boake (1956) that anticoagulase does not confer a solid immunity to experimental staphylococcal infection. At best only a prolongation of the life of an infected animal is possible. It is conceivable that coagulase may be of prime importance to the microorganism only in the early stages of the establishment of an infection. Once this has been accomplished, either naturally or by overwhelming challenge experimentally, coagulase may play a much less important role, and anticoagulase will produce only a delay in the inevitable outcome. 


\section{SUMMARY}

When coagulase negative hemolytic strains of Staphylococcus aureus are suspended in solutions of partially purified coagulase and injected intracerebrally into mice, a significant mortality results. Organisms alone or coagulase alone at the same dose level were innocuous.

Such virulence enhancement could not be demonstrated if the coagulase was given intravenously followed by intracerebral challenge, nor was coagulase able to enhance the virulence of streptococci.

It was shown that coagulase adsorbs to coagulase negative staphylococci, and it has been postulated that this may protect the microorganisms from the natural defense mechanisms of the host.

\section{REFERENCES}

BoAke, W. C. 1956 Antistaphylocoagulase in experimental staphylococcal infections. $J$. Immunol., 76, 89-96.

CoHn, Z. A., AND S. I. Morse 1959 Interactions between rabbit polymorphonuclear leukocytes and staphylococci. J. Exptl. Med., 110, 419443.

Ekstedt, R. D. 1956a Further studies on the antibacterial activity of human serum on Micrococcus pyogenes and its inhibition by coagulase. J. Bacteriol., 72, 157-161.
EKsTedt, R. D. $1956 b$ The effect of coagulase on the antibacterial activity of normal human serum against selected strains of Micrococcus pyogenes. Ann. N. Y. Acad. Sci., 65, 119-131.

Ekstedt, R. D., ANd W. J. Nungester 1955 Coagulase in reversing antibacterial activity of normal human serum on Micrococcus pyogenes. Proc. Soc. Exptl. Biol. Med., 89, 90-94.

Sмiтн, H. W. 1947 Examination of staphylococci of animal origin with particular regard to determination of criteria of pathogenicity. J. Comp. Pathol. Therap., 57, 98-115.

Smith, J. M., ANd R. J. Dubos 1956 The behavior of virulent and avirulent staphylococci in the tissues of normal mice. J. Exptl. Med., 103, 87-108.

TAGER, M. 1948 Concentration, partial purification, properties, and nature of staphylocoagulase. Yale J. Biol. Med., 20, 487-501.

Walker, B. S., N. K. Schaffer, and M. A. DEROw 1947 Inactivation of staphylocoagulase by trypsin and pepsin. Science, $106,347$.

WLODARCZAK, K., AND J. JELJASZEWICZ 1959 Influence of coagulase on the growth of staphylococci in normal human serum. Nature, 184, 1514-1515.

Yotis, W. W., ANd R. D. Eksted 1959 Studies on staphylococci. I. Effect of serum and coagulase on the metabolism of coagulase positive and coagulase negative strains. J. Bacteriol., 78, 567-574. 